\title{
Bulbar Conjunctivitis
}

National Cancer Institute

\section{Source}

National Cancer Institute. Bulbar Conjunctivitis. NCI Thesaurus. Code C112189.

Inflammation of the thin layer of tissue lining the sclera of the eye characterized by redness in the white portion of the eye. 